\title{
Molecular discrimination of cutaneous squamous cell carcinoma from actinic keratosis and normal skin
}

\author{
Seong Hui Ra, Xinmin Li and Scott Binder \\ Department of Pathology and Laboratory Medicine, David Geffen School of Medicine at UCLA, \\ Los Angeles, CA, USA
}

\begin{abstract}
Actinic keratosis is widely believed to be a neoplastic lesion and a precursor to invasive squamous cell carcinoma. However, there has been some debate as to whether actinic keratosis is in fact actually squamous cell carcinoma and should be treated as such. As the clinical management and prognosis of patients is widely held to be different for each of these lesions, our goal was to identify unique gene signatures using DNA microarrays to discriminate among normal skin, actinic keratosis, and squamous cell carcinoma, and examine the molecular pathways of carcinogenesis involved in the progression from normal skin to squamous cell carcinoma. Formalin-fixed and paraffin-embedded blocks of skin: five normal skins (pooled), six actinic keratoses, and six squamous cell carcinomas were retrieved. The RNA was extracted and amplified. The labeled targets were hybridized to the Affymetrix human U133plus2.0 array and the acquisition and initial quantification of array images were performed using the GCOS (Affymetrix). The subsequent data analyses were performed using DNA-Chip Analyzer and Partek Genomic Suite 6.4. Significant differential gene expression ( $>2$ fold change, $\boldsymbol{P}<0.05$ ) was seen with 382 differentially expressed genes between squamous cell carcinoma and normal skin, 423 differentially expressed genes between actinic keratosis and normal skin, and 9 differentially expressed genes between actinic keratosis and squamous cell carcinoma. The differentially expressed genes offer the possibility of using DNA microarrays as a molecular diagnostic tool to distinguish between normal skin, actinic keratosis, and squamous cell carcinoma. In addition, the differentially expressed genes and their molecular pathways could be potentially used as prognostic markers or targets for future therapeutic innovations.

Modern Pathology (2011) 24, 963-973; doi:10.1038/modpathol.2011.39; published online 1 April 2011
\end{abstract}

Keywords: actinic keratosis; differential gene expression; formalin-fixed and paraffin-embedded tissue; microarray; squamous cell carcinoma

Squamous cell carcinoma is the second most common cutaneous malignancy with over 250000 cases diagnosed per year. ${ }^{1}$ Although it is typically a straightforward diagnosis, there are many lesions, which may clinically and microscopically simulate cutaneous squamous cell carcinoma. Some of the lesions that can be the most difficult to differentiate, such as actinic keratosis and squamous cell carcinoma in situ, display varying different degrees of keratinocyte dysplasia and are typically considered

Correspondence: Dr S Binder, MD, Department of Pathology and Laboratory Medicine, David Geffen School of Medicine at UCLA, Box 951732, 13-186 CHS, Los Angeles, CA 90095-1732, USA.

E-mail: sbinder@mednet.ucla.edu

Received 11 June 2010; revised 16 October 2010; accepted 16 October 2010; published online 1 April 2011 neoplastic conditions. ${ }^{2}$ Although actinic keratosis is widely regarded as a neoplastic lesion that is a precursor to squamous cell carcinoma, some believe actinic keratosis is actually squamous cell carcinoma and should be treated as such. ${ }^{3,4}$ However, there is a consensus that differentiating between actinic keratosis and squamous cell carcinoma is important, as there are prognostic differences and treatment implications for the patient.

There have been only a few microarray studies to date that examined differential gene expression among cutaneous squamous lesions. ${ }^{5-8}$ These studies have been hampered by limited sample sizes, poor reproducibility, and the use of cell lines. ${ }^{5-8}$ We profiled and examined the gene expression of over 47000 genes using the most comprehensive GeneChip microarrays available (human U133 plus 
2.0 array), and identified differentially expressed genes among normal skin, actinic keratosis, and squamous cell carcinoma using formalin-fixed and paraffin-embedded tissue. Our goal was to identify unique gene signatures that can discriminate between normal skin, actinic keratosis, and squamous cell carcinoma, and examine the molecular pathways of carcinogenesis involved in the progression from normal skin to squamous cell carcinoma.

\section{Materials and methods}

\section{Sample Selection}

Six actinic keratoses, six squamous cell carcinomas, and five normal skins (pooled) were identified from the PowerPath database and the slides and paraffin blocks $(<6$ months old) were retrieved. The slides were reviewed by two of the authors (SHR, SB) and their diagnosis confirmed. Normal skin demonstrating mild sun damage in the form of solar elastosis was retrieved from cosmetics procedures. The areas of interest were removed from the paraffin blocks with a sterile surgical scalpel.

\section{RNA Isolation and Quality Control}

Total RNA was isolated using the Ambion RecoverAll (Applied Biosystems/Ambion, Austin, TX, USA) kit according to the manufacturer's instructions. Briefly, formalin-fixed and paraffin-embedded samples were deparaffinized using a series of xylene and ethanol washes, and then subjected to a proteinase $\mathrm{K}$ digestion at $50^{\circ} \mathrm{C}$ for $16 \mathrm{~h}$ to release RNA from covalently linked proteins. Finally, total RNA was purified by capture on a glass fiber filter. After washing, the total RNA was eluted. RNA Integrity was evaluated using an Agilent 2100 Bioanalyzer (Agilent Technologies, Palo Alto, CA, USA) and purity/concentration was determined using a NanoDrop 8000 (NanoDrop Products, Wilmington, DE, USA). The RNA samples with RNA Integrity Number (RIN) $\geq 5$ and $260: 280$ ratio $\geq 1.7$ were selected for the microarray.

\section{Target Preparation and Microarray Hybridization}

Microarray targets were prepared using NuGEN WTOvation formalin-fixed and paraffin-embedded RNA Amplification System V2. This system offers the most efficient cDNA amplification powered by Ribo-SPIA technology. It is, therefore, ideal for global gene expression analysis with the small amount of degraded RNA derived from formalin-fixed and paraffinembedded samples. Fifty nanograms of total RNA were used for the first-strand synthesis. After the second-strand cDNA synthesis, the double-stranded cDNA was purified using Agencourt RNAClean beads provided with the WT-Ovation kit, followed by SPIA cDNA Amplification. Amplified cDNA (5 $\mu \mathrm{g})$ was fragmented and labeled using NuGEN's FL-Ovation cDNA Biotin Module V2 according to the instructions (NuGEN Technologies, San Carlos, CA, USA), and then hybridized to the Affymetrix GeneChip U133plus 2.0 Array (Affymetrix, Santa Clara, CA, USA) according to manufacturer's instructions. The arrays were washed and stained with streptavidin phycoerythrin in Affymetrix Fluidics Station 450 using the Affymetrix GeneChip protocol and scanned using an Affymetrix GeneChip Scanner 3000.

\section{Data Analysis}

The acquisition and initial quantification of array images were conducted using the AGCC software (Affymetrix). The subsequent data analyses were performed using Partek Genomics Suite Version 6.4 (Partek, St Louis, MO, USA). We first performed a one-way ANOVA to identify genes between groups at $P<0.05$, and then calculated relative difference in fold change (FC) between groups. The genes at $\geq 2$ FC and $P<0.05$ were considered as differentially expressed between groups. Cluster analyses and principal component analysis were conducted with Partek default settings. The canonical pathway analyses were performed using Ingenuity Pathway Analysis Version 7.6 (Ingenuity Systems, Redwood City, CA, USA). Briefly, a differentially expressed gene list containing gene identifiers and corresponding FCs was first uploaded as an Excel spreadsheet into the software. Each gene identifier was mapped to its corresponding gene object in the Ingenuity Pathways Knowledge Base. These genes were then used as the starting point for pathway analysis. Canonical pathways analysis identified the pathways from the Ingenuity Pathways Analysis library of canonical pathways that were most significant to the data set. The significance of the association between the data set and the canonical pathway was measured in two ways: (1) ratio of the number of genes from the data set that map to the pathway divided by the total number of genes that map to the canonical pathway was displayed. (2) Fischer's exact test was used to calculate a $P$-value determining the probability that the association between the genes in the data set and the canonical pathway is explained by chance alone.

\section{Quantitative Real-Time PCR Analyses}

QRT-PCR confirmation was performed using NCode VILO miRNA cDNA synthesis Kit and NCode EXPRESS SYBR GreenER miRNA qRT-PCR Kit (Invitrogen) according to the manufacturer's instructions. The same RNAs for microarray hybridization were used for QRT-PCR confirmation. Applied Biosystems 7500 Real-Time PCR System was used for the analyses with the following primers:

S100A7: Left TGCTGACGATGATGAAGGAG; Right ATGTCTCCCAGCAAGGACAG 
S100A8: Left GAGCTGGAGAAAGCCTTGAA; Right AGACGTCTGCACCCTTTTTC

HOXC10: Left GCTGGTGTGTGTGTCAAACC; Right AACGATTCTGCCTGTGCTCT

C15orf48: Left AAGGGTGACCAAATGACGAG; Right TGCAGTTATTGCTGCACTCC

GAPDH was used as an internal control for normalization.

\section{Results}

The differential gene expression was compared between actinic keratosis and normal skin, squamous cell carcinoma and normal skin, and actinic keratosis and squamous cell carcinoma ( $>2 \mathrm{FC}$, $P<0.05$; Table 1). There were 382 differentially expressed genes between normal skin and squamous cell carcinoma with 290 downregulated and 92 upregulated. The most significantly upregulated genes (Table 2) included MMP1, SPRR1A/SPRR1B, ABCG4, S100A8, S100A9, WNT5a, and KRT6A. The most significantly downregulated genes included $D C D, H B A 1 / H B A 2, P I P, S C G B 1 D 2$, and C7.

There were 423 differentially expressed genes between normal skin and actinic keratosis with 326 downregulated and 97 upregulated. The most significantly upregulated genes (Table 2) included IGFL1, SPRR1A/SPRR1B, and KLK6 and calciumbinding proteins S100A7A, S100A8, and S100A9. The most significantly downregulated genes included DCD, CNN1, SCGB1D2, PIP, MYH11, and $H B A 1 / H B A 2$. There were nine differentially expressed genes between actinic keratosis and squamous cell carcinoma (Table 3). Upregulated genes included HOXC4, HOXC6, ROBO4, and COL6A3. Downregulated genes included RPL13A, CASZ1, RTN4 (Nogo-A), NFIB, and RPS6. Hierarchical cluster analysis using the list of the differentially expressed genes between squamous cell carcinoma and normal revealed a distinct genetic signature (Figure 1). To confirm the reliability of the results from microarray analysis, selected upregulated genes including S100A7, S100A8, and C15orf48 and downregulated gene HOXC10 were verified by QRT-PCR analyses (Figure 2).

The pathway analysis revealed 18 significantly enriched molecular pathways using the differentially expressed genes between squamous cell carcinoma and normal. The most significant enriched molecular pathways (Table 4 and Figure 3) included $\mathrm{WNT} / \beta$-catenin signaling, calcium signaling, integrin signaling, TR/RXR activation, and NFAT activation.

\section{Discussion}

The normal skin keratinocyte can undergo DNA damage and mutations by excessive exposure to UV radiation leading to the formation of actinic keratosis and then squamous cell carcinoma. ${ }^{9}$ It is widely believed that there is a stepwise progression from normal skin to actinic keratosis to squamous cell carcinoma. ${ }^{10-12}$ Although most accept this model of multistep carcinogenesis, there are some that believe that actinic keratosis is the same as squamous cell carcinoma and not a precursor lesion. ${ }^{3,4}$ This assertion is supported by one cDNA microarray study that showed no differentially expressed genes between actinic keratosis and squamous cell carcinoma. ${ }^{7}$ However, our data using the most sophisticated DNA microarray to date profiling over 47000 genes revealed that actinic keratosis and squamous cell carcinoma each has its own unique molecular signature and are therefore, distinct entities. Although actinic keratosis and squamous cell carcinoma displayed similar gene expression profiles and are closely related at the molecular level, there were nine genes in particular that were significantly differentially expressed (FC $>2, P<0.05$; Table 3).

Actinic keratosis and squamous cell carcinoma were distinguished by four upregulated genes and five downregulated genes. The upregulated genes HOXC4, HOXC6, and $\mathrm{ROBO} 4$ have been implicated in tumorigenesis. HOXC4 and HOXC6 are part of the homeobox family of genes and encode transcription factors that have a key role in morphogenesis and cell differentiation during embryogenesis of animals. HOXC6 has been found to modulate genes with both oncogenic and tumor suppressor activities, and has shown to be upregulated in prostate cancer and is correlated with its progression. ${ }^{13,14}$ $\mathrm{ROBO} 4$ is part of the roundabout family of receptors that are large, single-pass transmembrane cell surface receptors involved in directing cell migration in response to their cognate Slit ligands. They are best

Table 1 Summary of the differentially expressed genes in selected cutaneous squamous lesions

\begin{tabular}{lccc}
\hline Sample & $\begin{array}{c}\text { Total \# genes upregulated } \\
(>2 \text { fold change and } P<0.05)\end{array}$ & $\begin{array}{c}\text { Total \# genes downregulated } \\
(>2 \text { fold change and } P<0.05)\end{array}$ & $\begin{array}{c}\text { Total \# genes } \\
(>2 \text { fold change and } P<0.05)\end{array}$ \\
\hline Normal skin vs SCC & 92 & 290 & 382 \\
Normal skin vs AK & 97 & 326 & 423 \\
AK vs SCC & 4 & 5 & 9 \\
\hline
\end{tabular}


Table 2 Signature genes distinguishing normal skin from AK and SCC ( $>2$ fold change and $P<0.05$ )

\begin{tabular}{|c|c|c|c|c|c|}
\hline \multicolumn{2}{|c|}{ Normal skin vs squamous cell carcinoma } & \multirow[b]{2}{*}{$F C$} & \multicolumn{2}{|c|}{ Normal skin vs actinic keratosis } & \multirow[b]{2}{*}{$F C$} \\
\hline RefSeq & Symbol/gene & & RefSeq & Symbol/gene & \\
\hline \multicolumn{6}{|l|}{ Upregulated genes } \\
\hline NM_002421 & MMP1: matrix metallopeptidase 1 & 48.51 & NM_198541 & IGFL1: IGF-like family member 1 & 61.53 \\
\hline NM_005987 & $\begin{array}{l}\text { SPRR1A /// SPRR1B: small } \\
\text { proline-rich protein 1A /// small } \\
\text { proline-rich protein 1B (cornifin) }\end{array}$ & 7.13 & NM_176823 & $\begin{array}{l}\text { S100A7A: S100 calcium-binding } \\
\text { protein A7A }\end{array}$ & 9.12 \\
\hline NM_022169 & $\begin{array}{l}\text { ABCG4: ATP-binding cassette, } \\
\text { sub-family G (WHITE), member } 4\end{array}$ & 6.95 & NM_005987 & $\begin{array}{l}\text { SPRR1A /// SPRR1B: small } \\
\text { proline-rich protein 1A /// small } \\
\text { proline-rich protein 1B (cornifin) }\end{array}$ & 6.12 \\
\hline NM_002965 & $\begin{array}{l}\text { S100A9: S100 calcium-binding } \\
\text { protein A9 }\end{array}$ & 6.23 & $\begin{array}{l}\text { NM_001012964 /// } \\
\text { NM_001012965 /// } \\
\text { NM_002774 }\end{array}$ & $\begin{array}{l}\text { KLK6: kallikrein-related peptidase } \\
6\end{array}$ & 6.11 \\
\hline NM_005554 & KRT6A: keratin 6A & 5.81 & NM_002965 & $\begin{array}{l}\text { S100A9:S100 calcium-binding } \\
\text { protein A9 }\end{array}$ & 5.4 \\
\hline NM_002988 & $\begin{array}{l}\text { CCL18: chemokine (C-C motif) } \\
\text { ligand } 18 \text { (pulmonary and } \\
\text { activation-regulated) }\end{array}$ & 5.29 & NM_032563 & LCE3D: late-cornified envelope 3D & 5.31 \\
\hline NM_004004 & GJB2: gap junction protein, beta 2 & 5.19 & NM_002964 & $\begin{array}{l}\text { S100A8: S100 calcium-binding } \\
\text { protein A8 }\end{array}$ & 4.69 \\
\hline NM_002964 & $\begin{array}{l}\text { S100A8:S100 calcium-binding } \\
\text { protein A8 }\end{array}$ & 5.12 & NM_004004 & GJB2: gap junction protein, beta 2 & 4.39 \\
\hline NM_007315 & $\begin{array}{l}\text { STAT1: signal transducer and } \\
\text { activator of transcription } 1\end{array}$ & 4.68 & NM_003486 & $\begin{array}{l}\text { SLC7A5: solute carrier family } 7 \\
\text { (cationic amino acid transporter, } \\
\text { y+system), member } 5\end{array}$ & 4.35 \\
\hline NM_012397 & $\begin{array}{l}\text { SERPINB13: Serpin peptidase } \\
\text { inhibitor, clade B (ovalbumin), } \\
\text { member } 13\end{array}$ & 4.47 & NM_207373 & $\begin{array}{l}\text { C10orf99: chromosome } 10 \text { open- } \\
\text { reading frame } 99\end{array}$ & 4.3 \\
\hline NM_003392 & $\begin{array}{l}\text { WNT5A: wingless-type MMTV } \\
\text { integration site family, member } 5 \mathrm{~A}\end{array}$ & 4.35 & NM_005547 & IVL: involucrin & 4.06 \\
\hline \multicolumn{6}{|l|}{ Downregulated genes } \\
\hline NM_053283 & DCD: dermcidin & -1229.21 & NM_053283 & DCD: dermcidin & -1016.55 \\
\hline NM_000558 & $\begin{array}{l}\text { HBA1 /// HBA2: hemoglobin, } \\
\text { alpha } 1 \text { /// hemoglobin, alpha } 2\end{array}$ & -202.77 & NM_001299 & $\begin{array}{l}\text { CNN1: calponin 1, basic, smooth } \\
\text { muscle }\end{array}$ & -140.77 \\
\hline NM_002652 & PIP: prolactin-induced protein & -93.47 & NM_006551 & $\begin{array}{l}\text { SCGB1D2: secretoglobin, family } \\
\text { 1D, member } 2\end{array}$ & -121.49 \\
\hline NM_006551 & $\begin{array}{l}\text { SCGB1D2: secretoglobin, family } \\
\text { 1D, member } 2\end{array}$ & -73.51 & NM_002652 & PIP: prolactin-induced protein & -104.3 \\
\hline NM_000587 & C7: complement component 7 & -46.95 & $\begin{array}{l}\text { NM_001040113 /// } \\
\text { NM_001040114 /// } \\
\text { NM_002474 /// } \\
\text { NM_022844 }\end{array}$ & $\begin{array}{l}\text { MYH11: myosin, heavy chain } 11 \text {, } \\
\text { smooth muscle }\end{array}$ & -89.59 \\
\hline NM_003480 & $\begin{array}{l}\text { MFAP5: microfibrillar-associated } \\
\text { protein } 5\end{array}$ & -44.48 & NM_000558 & $\begin{array}{l}\text { HBA1 /// HBA2: hemoglobin, } \\
\text { alpha } 1 \text { /// hemoglobin, alpha } 2\end{array}$ & -55.81 \\
\hline NM_000518 & HBB: hemoglobin, beta & -41.39 & NM_173833 & $\begin{array}{l}\text { SCARA5: scavenger receptor class } \\
\text { A, member } 5 \text { (putative) }\end{array}$ & -31.62 \\
\hline NM_032411 & $\begin{array}{l}\text { C2orf } 40 \text { : chromosome } 2 \text { open- } \\
\text { reading frame } 40\end{array}$ & -34.75 & NM_000668 & $\begin{array}{l}\text { ADH1B: alcohol dehydrogenase 1B } \\
\text { (class I), beta polypeptide }\end{array}$ & -29.87 \\
\hline $\begin{array}{l}\text { NM_001040113 /// } \\
\text { NM_001040114 /// } \\
\text { NM_002474/// } \\
\text { NM_022844 }\end{array}$ & $\begin{array}{l}\text { MYH11: myosin, heavy chain } 11 \text {, } \\
\text { smooth muscle }\end{array}$ & -32.75 & NM_003480 & $\begin{array}{l}\text { MFAP5: microfibrillar-associated } \\
\text { protein } 5\end{array}$ & -28.15 \\
\hline
\end{tabular}

known for their role in neuronal development, but are now implicated in tumor angiogenesis. Increased $\mathrm{ROBO} 4$ expression has been demonstrated on tumor vessels of brain, colon, breast, kidney, and bladder neoplasms. ${ }^{15,16}$ Although COL6A3 has not been associated with tumorigenesis, alterations of extracellular matrix-binding proteins would seem necessary for progression and invasion of the dermis by squamous cell carcinoma.

The downregulated genes CASZ1, RTN4 (Nogo$A$ ), and $N F I B$ also have been associated with tumorigenesis. CASZ1 is a zinc-finger transcription factor that demonstrates increased expression in cells of neural origin as well as mesenchymal origin when they are induced to differentiate. CASZ1 was found to be expressed in a number of tumor cell lines of retinoblastoma, neuroblastoma, glioblastoma, and rhabdomyosarcoma origin. ${ }^{17}$ RTN4 is an axon regeneration inhibitor that was strongly expressed in the majority of oligodendrogliomas. It has also been found to be a helpful marker in distinguishing oligodendrogliomas from astrocytomas and ependymomas. ${ }^{18}$ RTN4 expression has also been negatively correlated with the malignancy grade of oligodendroglial tumors. ${ }^{19}$ NFIB is a transcription factor gene that has been associated with $M Y B-N F I B$ 
Table 3 Signature genes distinguishing AK from SCC ( $>2$ fold change and $P<0.05$ )

\begin{tabular}{|c|c|c|c|}
\hline RefSeq & Symbol/gene & Function & Fold change \\
\hline \multicolumn{4}{|l|}{ Upregulated genes } \\
\hline NM_004503 /// NM_153693 & HOXC6: homeobox C6 & $\begin{array}{l}\text { Sequence-specific transcription factors, which is } \\
\text { part of a developmental regulatory system that } \\
\text { provides cells with specific positional identities } \\
\text { on the anterior-posterior axis }\end{array}$ & 4.32 \\
\hline NM_014620 /// NM_153633 & HOXC4: homeobox C4 & & 2.87 \\
\hline NM_019055 & $\begin{array}{l}\text { ROBO4: roundabout homolog } \\
\text { 4, magic roundabout } \\
\text { (Drosophila) }\end{array}$ & $\begin{array}{l}\text { Receptor for Slit proteins, at least for SLIT2, and } \\
\text { seems to be involved in angiogenesis and } \\
\text { vascular patterning. May mediate the inhibition } \\
\text { of primary endothelial cell migration by Slit } \\
\text { proteins }\end{array}$ & 2.49 \\
\hline $\begin{array}{l}\text { NM_004369 /// NM_057164 /// } \\
\text { NM_057165 /// NM_057166 /// } \\
\text { NM_057167 }\end{array}$ & $\begin{array}{l}\text { COL6A3: collagen, type VI, } \\
\text { alpha } 3\end{array}$ & Extracellular matrix binding proteins & 2.08 \\
\hline \multicolumn{4}{|l|}{ Downregulated genes } \\
\hline $\begin{array}{l}\text { NM_007008 /// zNM_020532 /// } \\
\text { NM_153828 /// NM_207520 /// } \\
\text { NM_207521 }\end{array}$ & RTN4: reticulon 4 & $\begin{array}{l}\text { Reduces the anti-apoptotic activity of } \\
\text { Bcl-xl and Bcl-2 }\end{array}$ & -2.53 \\
\hline NM_001010 & RPS6: ribosomal protein S6 & $\begin{array}{l}\text { May have an important role in controlling cell } \\
\text { growth and proliferation through the selective } \\
\text { translation of particular classes of mRNA }\end{array}$ & -2.31 \\
\hline NM_005596 & NFIB: nuclear factor I/B & $\begin{array}{l}\text { These proteins are individually capable of } \\
\text { activating transcription and replication }\end{array}$ & -2.23 \\
\hline NM_001079843 /// NM_017766 & CASZ1: castor zinc-finger 1 & Probable transcription factor & -2.10 \\
\hline NM_012423 & $\begin{array}{l}\text { RPL13A: ribosomal protein } \\
\text { L13a }\end{array}$ & $\begin{array}{l}\text { Ribosomal protein that is a component of } \\
\text { the } 60 \mathrm{~S} \text { subunit }\end{array}$ & -2.02 \\
\hline
\end{tabular}

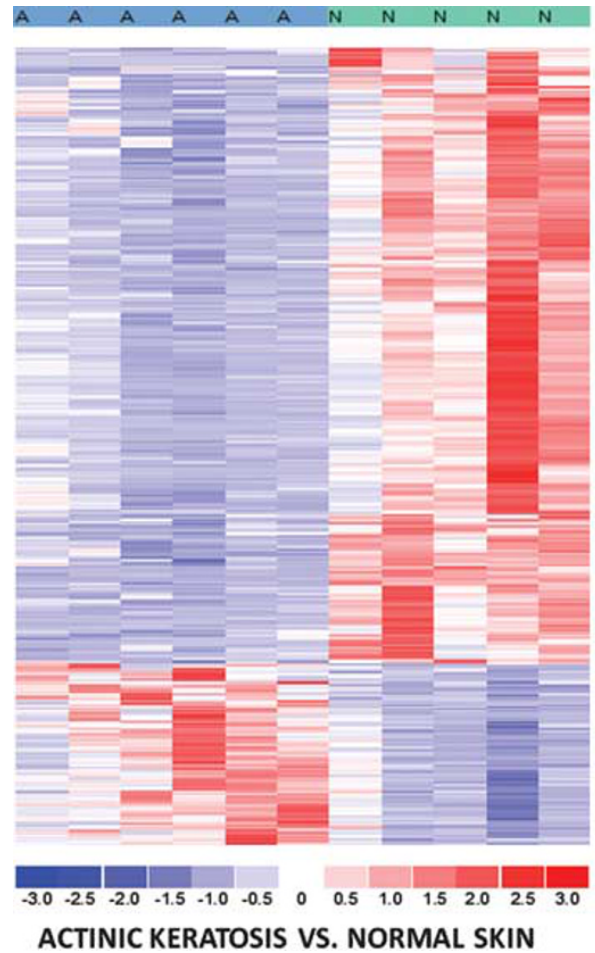

Figure 1 Hierarchical cluster analysis using the most significant differentially expressed genes ( $y$ axis) revealed that both actinic keratosis (A) vs normal skin $(\mathrm{N})$ and squamous cell carcinoma $(\mathrm{S})$ vs normal skin ( $x$ axis) demonstrated distinct genetic signatures. Downregulated genes are in blue and upregulated genes are in red.

fusion genes in adenoid cystic carcinomas of the breast and salivary glands and as a part of the HMGA2-NFIB fusion gene in lipomas. ${ }^{20-22}$ The

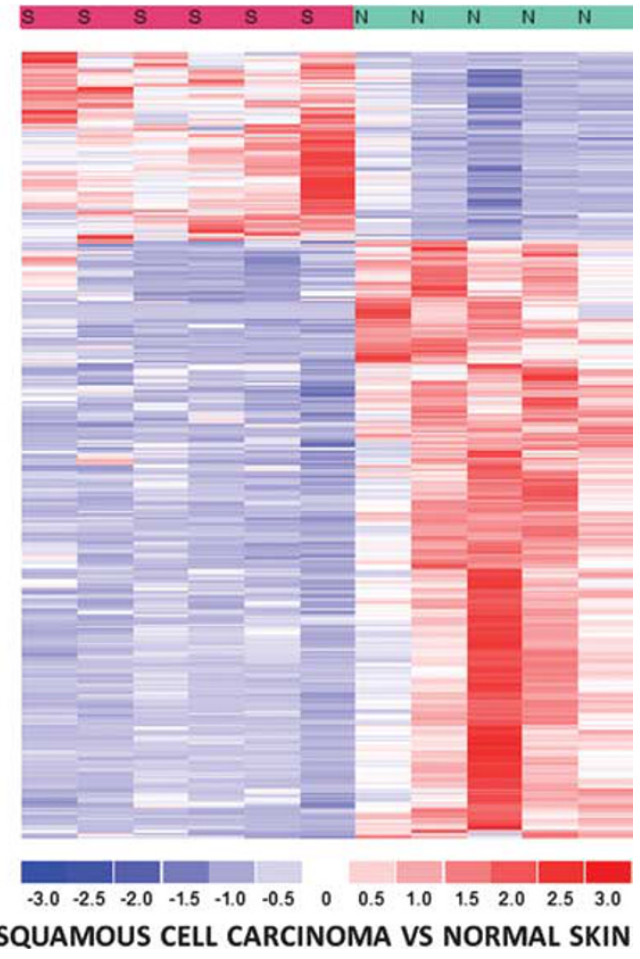


ribosomal proteins may be needed for the increased transcription of proteins necessary for the proliferation of tumor cells.

Our data showed that the evolution of squamous cell carcinoma from normal skin involves the participation of many different molecular pathways (Figure 3 and Table 4). The p53 signaling pathway

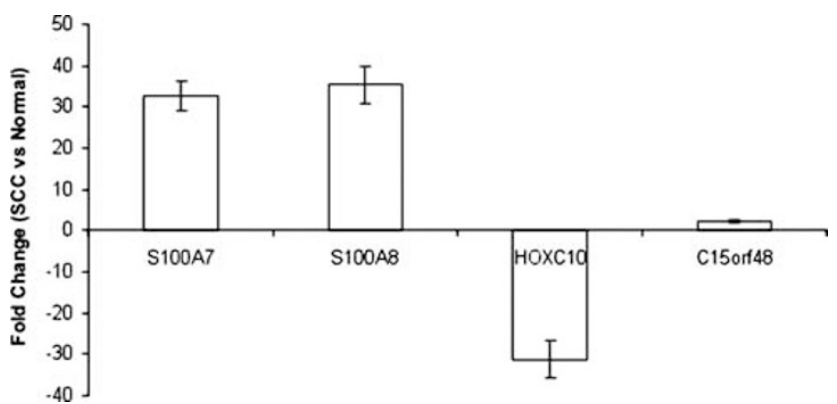

Figure 2 QRT-PCR analyses confirmed differential expression of the four representative genes between squamous cell carcinoma and normal samples. The $y$ axis represents fold change (squamous cell carcinoma vs normal). The bar on the column stands for the s.d. has been widely implicated in the tumorigenesis of cutaneous squamous cell carcinoma. Although there was deregulation of this pathway, the most significant alterations were in other pathways already implicated in carcinogenesis including $\mathrm{WNT} / \beta$-catenin signaling, calcium signaling, and integrin signaling. A description of these signaling pathways and their relationship with tumorigenesis is discussed below.

\section{Wnt/ק-catenin Signaling}

The Wnt/ $\beta$-catenin signaling pathway was the most significantly altered pathway in comparing squamous cell carcinoma to normal skin (-log $(P$-value $)=3.89)$. Wnt proteins are part of a large family of secreted glycoproteins that are involved in activating signal transduction pathways involved in numerous cellular processes including determination of cell fate, proliferation, migration, and polarity. ${ }^{23,24}$ Wnt proteins can mediate signaling through several pathways, the best characterized of

Table 4 Significantly enriched molecular pathways in the differentially expressed genes between normal skin and squamous cell carcinoma $(\mathrm{FC}>1.5$ and $P<0.05)$

\begin{tabular}{|c|c|c|}
\hline Molecular pathway & $\begin{array}{c}- \text { Log } \\
(P \text {-value })\end{array}$ & Molecules \\
\hline Wnt $/ \beta$-catenin signaling & 3.89 & $\begin{array}{l}\text { TCF4, PPARD, PPP2CA, SOX10, TGFBR3, TLE1, FZD1, SOX13, TCF3, CSNK1E, TLE3, } \\
\text { SFRP1, TCF7L2 (includes EG:6934), WNT5A }\end{array}$ \\
\hline Calcium signaling & 3.50 & $\begin{array}{l}\text { RAP2B, MYH10, TPM1, TRPC1, ITPR2, RCAN2, ACTA2, MEF2A (includes EG:4205), } \\
\text { MAPK6, MYH11, RCAN1, ATF2, PRKAG2, ASPH }\end{array}$ \\
\hline Integrin signaling & 3.47 & $\begin{array}{l}\text { RAP2B, ARPC5L (includes EG:81873), PIK3R1, ACTA2, MAPK6, PTK2, MYLK, ARF6, } \\
\text { ACTR3, RHOB, ARF3, ITGA9, PPP1R12A, ITGA7, ITGB5 }\end{array}$ \\
\hline TR/RXR activation & 3.34 & $\begin{array}{l}\text { AKR1C1, LDLR, AKR1C3, SLC2A1, PIK3R1, RCAN2, NCOA1, THRA (includes } \\
\text { EG:7067), DIO2 }\end{array}$ \\
\hline $\begin{array}{l}\text { Role of NFAT in regulation of the } \\
\text { immune response }\end{array}$ & 3.12 & $\begin{array}{l}\text { BLNK, ITPR2, PIK3R1, RCAN2, GNA11, MEF2A (includes EG:4205), MAPK6, RCAN1, } \\
\text { ATF2, CSNK1E, GNAI3, PLCB4, GNA15 }\end{array}$ \\
\hline $\begin{array}{l}\text { Hepatic fibrosis/hepatic stellate } \\
\text { cell activation }\end{array}$ & 3.05 & $\begin{array}{l}\text { COL1A2, MYH10, LEPR, ACTA2, PDGFRA, MYH11, IGFBP5, STAT1, MMP1 } \\
\text { (includes EG:4312), TIMP2, BCL2 }\end{array}$ \\
\hline IGF-1 signaling & 2.98 & $\begin{array}{l}\text { YWHAQ (includes EG:10971), PTK2, NOV, PIK3R1, FOXO3, MAPK6, PRKAG2, } \\
\text { IGFBP5, IRS2 }\end{array}$ \\
\hline GNRH signaling & 2.80 & PTK2, ADCY9, GNAI3, PLCB4, ITPR2, GNA11, MAPK6, PRKAG2, MAP2K3, ATF2 \\
\hline $\begin{array}{l}\text { Corticotropin-releasing hormone } \\
\text { signaling }\end{array}$ & 2.52 & $\begin{array}{l}\text { ADCY9, GNAI3, IVL, ITPR2, PTCH1, MEF2A (includes EG:4205), MAPK6, PRKAG2, } \\
\text { ATF2 }\end{array}$ \\
\hline Dopamine receptor signaling & 2.40 & ADCY9, GCH1, PPP2CA, PRKAG2, PPP1R12A, SMOX, MAOA \\
\hline CXCR4 signaling & 2.39 & $\begin{array}{l}\text { PTK2, ADCY9, GNAI3, PLCB4, RHOB, GNA15, ITPR2, CXCL12, PIK3R1, GNA11, } \\
\text { MAPK6 }\end{array}$ \\
\hline Molecular mechanisms of cancer & 2.37 & $\begin{array}{l}\text { RAP2B, ADCY9, TCF4, PIK3R1, GNA11, PTCH1, MAPK6, FZD1, TCF3, BCL2, PTK2, } \\
\text { GNAI3, PLCB4, RABIF, RHOB, GNA15, PRKAG2, MAP2K3, WNT5A }\end{array}$ \\
\hline Leukocyte extravasation signaling & 2.34 & $\begin{array}{l}\text { PTK2, GNAI3, TIMP3, CLDN11, CLDN8, JAM3, CXCL12, PIK3R1, ACTA2, PECAM1, } \\
\text { MMP1 (includes EG:4312), TIMP2 }\end{array}$ \\
\hline Xenobiotic metabolism signaling & 2.32 & $\begin{array}{l}\text { PPP2CA, GSTM3 (includes EG:2947), PIK3R1, MAPK6, ALDH9A1, HMOX1, UST, CAT, } \\
\text { NCOA1, SMOX, MAP2K3, NDST1, ALDH6A1, MAOA }\end{array}$ \\
\hline Oncostatin M signaling & 2.32 & TIMP3, MAPK6, PLAU, STAT1, MMP1 (includes EG:4312) \\
\hline Axonal guidance signaling & 2.23 & $\begin{array}{l}\text { DPYSL2, SLIT3, ARPC5L (includes EG:81873), PIK3R1, GNA11, PTCH1, MAPK6, } \\
\text { FZD1, NTN1, PTK2, GNAI3, PLCB4, NTRK2, ACTR3, GNA15, CXCL12, ABLIM3, } \\
\text { PRKAG2, WNT5A }\end{array}$ \\
\hline $\begin{array}{l}\text { Cholecystokinin/gastrin-mediated } \\
\text { signaling }\end{array}$ & 2.15 & PTK2, PLCB4, RHOB, ITPR2, MEF2A (includes EG:4205), MAPK6, MAP2K3, ATF2 \\
\hline p53 Signaling & 1.34 & SCO2 (includes EG:9997), PLAGL1, PIK3R1, CABC1, PERP, BCL2 \\
\hline
\end{tabular}




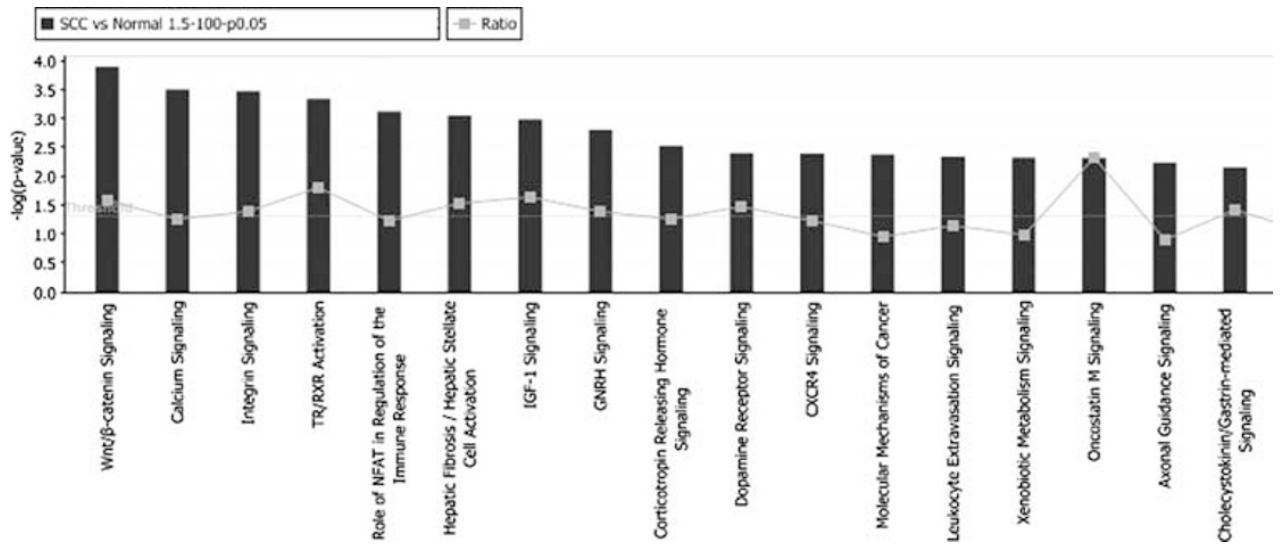

Figure 3 The most significantly deregulated molecular pathways ( $x$ axis) comparing squamous cell carcinoma vs normal skin $($ FC $>1.5, P<0.05)$ utilizing the $[-\log (P$-value $)]$ on the $y$ axis. The horizontal line represents the threshold for significance $(P<0.05)$.

which is the $\beta$-catenin/Tcf-mediated pathway. Deregulation of the $\mathrm{Wnt} / \beta$-catenin signaling pathway leads to continuous transcription of many target genes involved in cell proliferation such as $C-M Y C$ and cyclin D1. ${ }^{23,24}$ Constitutive activation of this pathway has been identified in sporadic colon cancers and inherited familial adenomatous polyposis. ${ }^{25}$ Abnormalities in this pathway have also been implicated in melanoma and carcinomas from the breast, liver, prostate, and stomach. ${ }^{25,26}$

\section{Calcium Signaling}

Calcium signaling was one of the most significantly altered pathways $(-\log (P$-value $)=3.50)$. Calcium is a universal ubiquitous intracellular messenger that has a vital role in many cellular processes. Calcium homeostasis is important in the orderly progression of the cell cycle, regulation of cell proliferation and growth, and apoptosis. ${ }^{27}$ Deregulation of these intricate calcium signaling pathways has been implicating in tumorigenesis by evasion of apoptosis and the acquisition of self-sustaining growth signals. ${ }^{27}$ The mechanisms of the deregulation of calcium signaling have been shown through T-type calcium channels, calcium pumps/exchangers, vitamin $\mathrm{D}$, and calcium-sensing receptors. ${ }^{27-33}$ Calcium and vitamin $\mathrm{D}$ pathways have been found to be especially important in activating the genetic pathways required for keratinocyte differentiation. ${ }^{34,35}$ Bikle et $a l^{35}$ showed that squamous cell carcinoma cell lines failed to respond to the prodifferentiating actions of vitamin D. Alterations of calcium signaling have also been linked to carcinomas of breast, colon, esophagus, liver, ovarian, and prostate origin. ${ }^{27-29,33,36,37}$ These findings suggest a strong association between disruptions of calcium signaling and carcinogenesis and may provide targets for future therapeutic interventions by targeting of these pathways.

\section{Integrin Signaling}

Integrin signaling was another one of the most significantly altered pathways $(-\log (P$-value $)=$ 3.47). Integrins are a family of transmembrane cell adhesion receptors that are integral to numerous intracellular signaling pathways that are vital to adhesion, migration, polarity, differentiation, and apoptosis of the cell. ${ }^{38,39}$ Integrins transduce bidirectional signals from inside-out and outside-in the cell, thus representing the cellular link to the external environment. Integrins have been well studied in carcinogenesis and have been implicated in tumor cell proliferation and the inhibition of apoptosis through signal transduction pathways, such as Raf-ERK/MAPK, PI3K-Akt, nuclear factorkappa B, and Jun. ${ }^{38,39}$ Integrins have major roles in metastasis, invasion of the extracellular matrix, metastasis, and angiogenesis. The aberrant expression of certain integrins has been associated with decreased patient survival in breast carcinoma, cervical carcinoma, and colon carcinoma. ${ }^{40-42}$ Lymph node and bone metastases have been associated with specific integrins in melanoma, breast carcinoma, prostate carcinoma, and pancreatic carcinoma. ${ }^{43-47}$ The use of integrin antagonists in glioblastoma and colorectal carcinoma as a therapeutic modality has shown promise in clinical trials. ${ }^{48,49}$ The finding of deregulated integrin signaling in our study is not surprising as the upregulation of different integrins has been previously demonstrated in cutaneous squamous cell carcinomas. ${ }^{50,51}$

\section{P53 Signaling}

The P53 signaling pathway has been widely implicated in the pathogenesis with P53 mutations having been identified in $69 \%$ to over $90 \%$ of invasive squamous cell carcinomas. ${ }^{52-54}$ p53 encodes a tumor suppressor protein that functions as a 
Table 5 All of the microarray studies to date comparing differential gene expression between SCC and normal skin

\begin{tabular}{|c|c|c|c|c|c|c|c|}
\hline Study/year & Samples & $\begin{array}{l}\text { Genes } \\
\text { examined }\end{array}$ & $\begin{array}{l}\text { Differentially } \\
\text { expressed } \\
\text { genes }\end{array}$ & $\begin{array}{l}\text { Upregulated } \\
\text { genes }\end{array}$ & $\begin{array}{l}\text { Downregulated } \\
\text { genes }\end{array}$ & $\begin{array}{l}\text { Significant } \\
\text { upregulated } \\
\text { genes }\end{array}$ & $\begin{array}{l}\text { Significant } \\
\text { downregulated } \\
\text { genes }\end{array}$ \\
\hline $\begin{array}{l}\text { Dooley } \\
\text { et } a l^{5}\end{array}$ & $\begin{array}{l}5 \text { SCC cell lines, } \\
1 \text { normal cell } \\
\text { line, } 4 \text { SCC skin }\end{array}$ & $\begin{array}{l}7400 ; \\
\text { DermArray } \\
\text { and } \\
\text { PharmArray }\end{array}$ & 96 & 96 & N/A & $\begin{array}{l}\text { FN1, HAPIP, G3P2, } \\
\text { ANXA5, ZNF254 }\end{array}$ & N/A \\
\hline $\begin{array}{l}\text { Nindl } \\
\text { et } a l^{7}\end{array}$ & $\begin{array}{l}5 \text { SCC skin, } 4 \\
\text { AK skin, } 6 \\
\text { normal skin }\end{array}$ & $\begin{array}{l}22283 ; \\
\text { Affymetrix } \\
\text { HG-U133A }\end{array}$ & 118 & $42(36 \%)$ & $76(64 \%)$ & $\begin{array}{l}\text { CDHI, MAP4K4, } \\
\text { IL-IRN, IL-4R, } \\
\text { NMI, GRN, RAB31, } \\
\text { TNC, } M M P 1\end{array}$ & $\begin{array}{l}\text { ERCCI, APR-3, } \\
\text { CGI-39, NKEFB }\end{array}$ \\
\hline $\begin{array}{l}\text { Kathpalia } \\
\text { et } a l^{6}\end{array}$ & $\begin{array}{l}5 \text { SCC skin, } 5 \\
\text { normal skin }\end{array}$ & $\begin{array}{l}12627 ; \\
\text { Affymetrix } \\
\text { U95A }\end{array}$ & 73 & $37(51 \%)$ & $36(49 \%)$ & $\begin{array}{l}\text { BCL2A1, MUC4, } \\
\text { PTPN11, FGF9 }\end{array}$ & N/A \\
\hline $\begin{array}{l}\text { Haider } \\
\text { et } a l^{8}\end{array}$ & $\begin{array}{l}8 \text { SCC skin, } 8 \\
\text { normal skin }\end{array}$ & $\begin{array}{l}>12000 \\
\text { Affymetrix } \\
\text { U95A }\end{array}$ & 117 & $86(74 \%)$ & $31(26 \%)$ & $\begin{array}{l}\text { FZD6, PTN, } \\
\text { CTSL2, MMP1, } \\
\text { MMP10, MMP13, } \\
\text { CDK7, CDC7, } \\
\text { EREG, E2F3, } \\
\text { WNT5a, }\end{array}$ & $\begin{array}{l}\text { TIMP3, NFKB2, } \\
\text { NFKBIA, } \\
\text { VEGFC, CD69 }\end{array}$ \\
\hline $\begin{array}{l}\text { Current } \\
\text { study }\end{array}$ & $\begin{array}{l}6 \text { SCC skin, } 6 \\
\text { AK skin, } 5 \\
\text { normal skin }\end{array}$ & $\begin{array}{l}>47000 ; \\
\text { U133plus2.0 } \\
\text { array }\end{array}$ & 382 & $92(24 \%)$ & $290(76 \%)$ & $\begin{array}{l}\text { MMP1, WNT5a } \\
\text { SPRR1A/SPRR1B, } \\
\text { S100A8,S100A9, } \\
\text { KRT6A, ABCG4 }\end{array}$ & $\begin{array}{l}\text { DCD, SCGB1D2, } \\
\text { HBA1/HBA2, } \\
\text { PIP, C7 }\end{array}$ \\
\hline
\end{tabular}

DNA-binding transcription factor that is critically involved in the regulation of cell cycle control and apoptosis. ${ }^{55}$ Upregulation of p53 occurs in response to a variety of cellular stresses including DNA damage, oncogenic stimulation, hypoxia, oxidative stress, or telomere shortening. ${ }^{54}$ Ultraviolet light is thought to have a major role in the carcinogenesis of squamous cell carcinoma by causing DNA damage, mutations in the p53 gene, and immunosuppression. ${ }^{54,55}$ Although our study revealed a statistically significant alteration of the p53 pathway in squamous cell carcinoma compared with normal skin $(-\log (P$-value $)=1.34)$, many other pathways showed considerably more deregulation. In keeping with the concept of multistep carcinogenesis, the dysregulation of other molecular pathways in conjunction with or independent of the p53 signaling pathway may be necessary for the evolution of squamous cell carcinoma from normal skin.

Significantly overexpressed genes distinguishing squamous cell carcinoma from normal skin included WNT5a and MMP1. These genes have also been found to be consistently overexpressed in other microarray and RT-PCR studies comparing cutaneous squamous cell carcinoma with normal skin. ${ }^{7,8,56}$ WNT5a and MMP1 have also been found to be overexpressed in squamous cell carcinoma from other anatomic sites, including the lip, oral cavity, head and neck, and lung. WNT5A is a member of the Wnt family of proteins (discussed previously) and was found to be significantly overexpressed in squamous cell carcinoma in comparison with normal skin in our study $(\mathrm{FC}=4.35$; Table 2). WNT5a was found to be overexpressed in another microarray study comparing cutaneous squamous cell carcinoma with normal skin. ${ }^{8}$
Upregulation of WNT5a appears conserved in squamous cell carcinomas from different anatomic locations, including the lip, head and neck, and lung, and appears to be an important gene in the tumorigenesis of squamous cell carcinoma. ${ }^{56-58}$ Upregulation of WNT5a has been identified in many different malignancies, including melanoma and carcinomas from the breast, esophagus, lung, pancreas, and stomach. ${ }^{59-63}$

MMP1 was found to be the most overexpressed gene in squamous cell carcinoma in comparison with normal skin ( $\mathrm{FC}=48.51$; Table 2$)$. $M M P 1$ is one of the proteins of the matrix metalloproteinase family that are involved in the breakdown of extracellular matrix in normal physiological processes, such as embryonic development, reproduction, and tissue remodeling. ${ }^{64,65}$ Matrix metallopeptidases have been shown to have an important role in tumorigenesis by proteolytic destruction of extracellular matrix and basement membranes, facilitating tumor invasion and metastasis. ${ }^{65,66}$ Matrix metallopeptidases have also been implicated in the early phases of tumor evolution, including stimulation of cell proliferation and modulation of angiogenesis. ${ }^{65} M M P 1$ is one of the rare genes consistently overexpressed in the different microarray studies examining cutaneous squamous cell carcinomas in comparison with normal skin., ${ }^{7,8}$ Upregulation of $M M P 1$ appears to a conserved in squamous cell carcinomas from different anatomic locations including the head and neck and oral cavity. ${ }^{67-70}$ Matrix metallopeptidases appear integral to tumorigenesis and have been targeted by inhibitors; however, clinical trials of advanced lung, prostate, pancreas, brain, and GI tract malignancies have shown little efficacy to date. ${ }^{64,71}$ More data may 
be needed before a successful clinical trial is completed. ${ }^{64}$

One surprising finding was that more differentially expressed genes were identified when comparing actinic keratosis with normal skin (423 genes) than comparing squamous cell carcinoma with normal skin (390 genes). Similarly, a study by Rehman et $a l^{72}$ found that actinic keratoses showed higher rates of loss of heterozygosity of various chromosomes than squamous cell carcinoma. These results suggest that the relationship between the accumulation of genetic change, phenotype, and behavior for squamous cell carcinoma is not a straightforward progression from normal skin. It is possible that the presence of these additional altered genes/pathways in actinic keratoses is responsible for counteracting or delaying the incremental acquisition of additional deleterious mutations in the evolution of actinic keratosis to squamous cell carcinoma. An alternative explanation is that the initiation stage from the evolution of normal skin to actinic keratosis requires the involvement of various complex molecular signaling pathways, whereas the transformation from actinic keratosis to squamous cell carcinoma requires the involvement of more specific pathways. Clearly more work is needed in this area to clearly elucidate the genes/pathways leading to the formation of invasive squamous cell carcinoma.

Our microarray study revealed the greatest number of differentially expressed genes in comparison with previous microarray studies evaluating squamous cell carcinoma from normal skin (Table 5) and a unique gene signature distinguishing actinic keratosis from squamous cell carcinoma. ${ }^{5-8}$ These discrepancies from previous studies are likely due to the type of tissues analyzed (cell line vs fresh tissue vs formalin-fixed and paraffin-embedded tissue) and advances in microarray technology including increasingly sophisticated RNA isolation techniques from formalinfixed and paraffin-embedded tissue. We also utilized the most comprehensive microarray (Affymetrix U133plus2.0 array) to date that examined over 47000 genes. With further advances in microarray technology and techniques to analyze the data, it is likely that more differentially expressed genes and their pathways will be identified.

\section{Conclusion}

The DNA microarrays were able to distinguish among normal skin, actinic keratosis, and squamous cell carcinoma. The differentially expressed genes between actinic keratosis and squamous cell carcinoma and their cancer-related functions demonstrate that they are distinct lesions and not the same entity. These differentially expressed genes may prove useful in the differentiation of these lesions in cases in which the histological diagnosis may be difficult because of sparse or superficial sampling and poor orientation of the specimen. We hope that some of the differentially expressed genes that we have identified may serve as potential biomarkers for disease prognosis or targets for future therapeutic interventions.

\section{Disclosure/conflict of interest}

The authors declare no conflict of interest.

\section{References}

1 Alam M, Ratner D. Cutaneous squamous cell carcinoma. N Eng J Med 2001;344:975-983.

2 Smoller BR. Squamous cell carcinoma: from precursor lesions to high-risk variants. Mod Pathol 2006;19 (Suppl 2):S88-S92.

3 Ackerman AB, Mones JM. Solar (actinic) keratosis is squamous cell carcinoma. Br J Dermatol 2006;155:9-22.

4 Lober BA, Lober CW. Actinic keratosis is squamous cell carcinoma. South Med J 2000;93:650-655.

5 Dooley TP, Reddy SP, Wilborn TW, et al. Biomarkers of human cutaneous squamous cell carcinoma from tissues and cell lines identified by DNA microarrays and qRT-PCR. Biochem Biophys Res Commun 2003;11:1026-1036.

6 Kathpalia VP, Mussactinic keratosis EN, Chow SS, et al. Genome-wide transcriptional profiling in human squamous cell carcinoma of the skin identifies unique tumorassociated signatures. J Dermatol 2006;33:309-318.

7 Nindl I, Dang C, Forschner T, et al. Identification of differentially expressed genes in cutaneous squamous cell carcinoma by microarray expression profiling. Mol Cancer 2006;5:30.

8 Haider AS, Peters SB, Kaporis H, et al. Genomic analysis defines a cancer-specific gene expression signature for human squamous cell carcinoma and distinguishes malignant hyperproliferation from benign hyperplasia. J Invest Dermatol 2006;126:869-881.

9 Serewko MM, Popa C, Dahler AL, et al. Alterations in gene expression and activity during squamous cell carcinoma development. Cancer Res 2002;62:3759-3765.

10 Czarnecki D, Meehan CJ, Bruce F, et al. The majority of cutaneous squamous cell carcinomas arise in actinic keratoses. J Cutan Med Surg 2002;6:207-209.

$11 \mathrm{Fu}$ W, Cockerell CJ. The actinic (solar) keratosis: a 21stcentury perspective. Arch Dermatol 2003;139:66-70.

12 Cassarino DS, Derienzo DP, Barr RJ. Cutaneous squamous cell carcinoma: a comprehensive clinicopathologic classification. J Cutan Pathol 2006;33:191-206.

13 Ramachandran S, Liu P, Young AN, et al. Loss of HOXC6 expression induces apoptosis in prostate cancer cells. Oncogene 2005;24:188-198.

14 McCabe CD, Spyropoulos DD, Martin D, et al. Genomewide analysis of the homeobox C6 transcriptional network in prostate cancer. Cancer Res 2008;68:1988-1996.

15 Legg JA, Herbert JM, Clissold P, et al. Slits and roundabouts in cancer, tumour angiogenesis and endothelial cell migration. Angiogenesis 2008;11:13-21.

16 Gröne J, Doebler O, Loddenkemper C, et al. Robo1/ Robo4: differential expression of angiogenic markers in colorectal cancer. Oncol Rep 2006;15:1437-1443.

17 Liu Z, Yang X, Tan F, et al. Molecular cloning and characterization of human Castor, a novel human gene upregulated during cell differentiation. Biochem Biophys Res Commun 2006;344:834-844. 
18 Kuhlmann T, Gutenberg A, Schulten HJ, et al. Nogo-a expression in glial CNS tumors: a tool to differentiate between oligodendrogliomas and other gliomas? Am J Surg Pathol 2008;32:1444-1453.

19 Xiong NX, Zhao HY, Zhang FC, et al. Negative correlation of Nogo-A with the malignancy of oligodendroglial tumor. Neurosci Bull 2007;23:41-45.

20 Pierron A, Fernandez C, Saada E, et al. HMGA2-NFIB fusion in a pediatric intramuscular lipoma: a novel case of NFIB alteration in a large deep-seated adipocytic tumor. Cancer Genet Cytogenet 2009;195:66-70.

21 Nilsson M, Panagopoulos I, Mertens F, et al. Fusion of the HMGA2 and NFIB genes in lipoma. Virchows Arch 2005;447:855-858.

22 Marchiò C, Weigelt B, Reis-Filho JS. Adenoid cystic carcinomas of the breast and salivary glands (or 'The strange case of Dr Jekyll and Mr Hyde' of exocrine gland carcinomas). J Clin Pathol 2010;63:220-228.

23 Kikuchi A, Yamamoto $H$. Tumor formation due to abnormalities in the beta-catenin-independent pathway of Wnt signaling. Cancer Sci 2008;99:202-208.

24 Miller JR, Hocking AM, Brown JD, et al. Mechanism and function of signal transduction by the Wnt/betacatenin and Wnt/Ca2+ pathways. Oncogene 1999;18:7860-7872.

25 Jin T, George Fantus I, Sun J. Wnt and beyond Wnt: multiple mechanisms control the transcriptional property of beta-catenin. Cell Signal 2008;20:1697-1704.

26 Paul S, Dey A. Wnt signaling and cancer development: therapeutic implication. Neoplasma 2008;55:165-176.

27 Capiod T, Shuba Y, Skryma R, et al. Calcium signalling and cancer cell growth. Subcell Biochem 2007;45: 405-427.

28 Whitfield JF. Calcium, calcium-sensing receptor and colon cancer. Cancer Lett 2009;275:9-16.

29 Sergeev IN. Calcium signaling in cancer and vitamin D. J Steroid Biochem Mol Biol 2005;97:145-151.

30 Taylor JT, Zeng XB, Pottle JE, et al. Calcium signaling and T-type calcium channels in cancer cell cycling. World J Gastroenterol 2008;14:4984-4991.

31 Panner A, Wurster RD. T-type calcium channels and tumor proliferation. Cell Calcium 2006;40:253-259.

32 Rodland KD. The role of the calcium-sensing receptor in cancer. Cell Calcium 2004;35:291-295.

33 Chactinic keratosisravarti B, Dwivedi SK, Mithal A, et al. Calcium-sensing receptor in cancer: good cop or bad cop? Endocrine 2009;35:271-284.

34 Bikle DD, Oda Y, Xie Z. Calcium and 1,25(OH)2D: interacting drivers of epidermal differentiation. J Steroid Biochem Mol Biol 2004;89-90:355-360.

35 Bikle DD. Vitamin D regulated keratinocyte differentiation. J Cell Biochem 2004;92:436-444.

36 Lu F, Chen H, Zhou C, et al. T-type Ca2+ channel expression in human esophageal carcinomas: a functional role in proliferation. Cell Calcium 2008;43: 49-58.

37 Li Y, Liu S, Lu F, et al. A role of functional T-type Ca2+ channel in hepatocellular carcinoma cell proliferation. Oncol Rep 2009;22:1229-1235.

38 Moschos SJ, Drogowski LM, Reppert SL, et al. Integrins and cancer. Oncology (Williston Park) 2007;21(9 Suppl 3):13-20.

39 Desgrosellier JS, Cheresh DA. Integrins in cancer: biological implications and therapeutic opportunities. Nat Rev Cancer 2010;10:9-22.

40 Friedrichs K, Ruiz P, Franke F, et al. High expression level of alpha 6 integrin in human breast carcinoma is correlated with reduced survival. Cancer Res 1995;55:901-906.

41 Hazelbag S, Kenter GG, Gorter A, et al. Overexpression of the alpha v beta 6 integrin in cervical squamous cell carcinoma is a prognostic factor for decreased survival. J Pathol 2007;212:316-324.

42 Bates RC, Bellovin DI, Brown C, et al. Transcriptional activation of integrin beta6 during the epithelialmesenchymal transition defines a novel prognostic indicator of aggressive colon carcinoma. J Clin Invest 2005;115:339-347.

43 Hieken TJ, Ronan SG, Farolan M, et al. Molecular prognostic markers in intermediate-thickness cutaneous malignant melanoma. Cancer 1999;85:375-382.

44 Sloan EK, Pouliot N, Stanley KL, et al. Tumor-specific expression of alphavbeta3 integrin promotes spontaneous metastasis of breast cancer to bone. Breast Cancer Res 2006;8:R20.

45 McCabe NP, De S, Vasanji A, et al. Prostate cancer specific integrin alphavbeta3 modulates bone metastatic growth and tissue remodeling. Oncogene 2007;26:6238-6243.

46 Hosotani R, Kawaguchi M, Masui T, et al. Expression of integrin alphaVbeta3 in pancreatic carcinoma: relation to MMP-2 activation and lymph node metastasis. Pancreas 2002;25:e30-e35.

47 Morozevich G, Kozlova N, Cheglactinic keratosisov I, et al. Integrin alpha5beta1 controls invasion of human breast carcinoma cells by direct and indirect modulation of MMP-2 collagenase activity. Cell Cycle 2008;15:2219-2225.

48 MacDonald TJ, Stewart CF, Kocactinic keratosis M, et al. Phase I clinical trial of cilengitide in children with refractory brain tumors: Pediatric Brain Tumor Consortium Study PBTC-012. J Clin Oncol 2008;26:919-924.

49 Le Tourneau C, Faivre S, Raymond E. The role of integrins in colorectal cancer. Oncology (Williston Park) 2007;21(9 Suppl 3):21-24.

50 Orimoto AM, Neto CF, Pimentel ER, et al. High numbers of human skin cancers express MMP2 and several integrin genes. J Cutan Pathol 2008;35:285-291.

51 Janes SM, Watt FM. New roles for integrins in squamouscell carcinoma. Nat Rev Cancer 2006;6:175-183.

52 Brash DE, Ziegler A, Jonason AS, et al. Sunlight and sunburn in human skin cancer: p53, apoptosis, and tumor promotion. J Investig Dermatol Symp Proc 1996;1:136-142.

53 Nelson MA, Einspahr JG, Alberts DS, et al. Analysis of the p53 gene in human precancerous actinic keratosis lesions and squamous cell cancers. Cancer Lett 1994;85:23-29.

54 Benjamin CL, Melnikova VO, Ananthaswamy HN. P53 protein and pathogenesis of melanoma and nonmelanoma skin cancer. Adv Exp Med Biol 2008;624:265-282.

55 Tactinic keratosisata M, Saida T. Early cancers of the skin: clinical, histopathological, and molecular characteristics. Int J Clin Oncol 2005;10:391-397.

56 Al Moustafa AE, Alaoui-Jamali MA, Batist G, et al. Identification of genes associated with head and neck carcinogenesis by cDNA microarray comparison between matched primary normal epithelial and squamous carcinoma cells. Oncogene 2002;21: 2634-2640.

57 Xavier FC, Rodini CO, Ramalho LM, et al. WNT-5A, but not matrix metalloproteinase 3 or beta-catenin protein, expression is related to early stages of lip carcinogenesis. J Oral Pathol Med 2009;38:708-715. 
58 Lee EH, Chari R, Lam A, et al. Disruption of the noncanonical WNT pathway in lung squamous cell carcinoma. Clin Med Oncol 2008;2008:169-179.

59 Saitoh T, Mine T, Katoh M. Frequent up-regulation of WNT5A mRNA in primary gastric cancer. Int J Mol Med 2002;9:515-519.

60 Saitoh T, Katoh M. Expression and regulation of WNT5A and WNT5B in human cancer: up-regulation of WNT5A by TNFalpha in MKN45 cells and upregulation of WNT5B by beta-estradiol in MCF-7 cells. Int J Mol Med 2002;10:345-349.

61 Lejeune S, Huguet EL, Hamby A, et al. Wnt5a cloning, expression, and up-regulation in human primary breast cancers. Clin Cancer Res 1995;1:215-222.

62 Bachmann IM, Straume O, Puntervoll HE, et al. Importance of P-cadherin, beta-catenin, and Wnt5a/ frizzled for progression of melanocytic tumors and prognosis in cutaneous melanoma. Clin Cancer Res 2005;11:8606-8614.

63 Da Forno PD, Pringle JH, Hutchinson P, et al. WNT5A expression increases during melanoma progression and correlates with outcome. Clin Cancer Res 2008;14: 5825-5832.

64 Dormán G, Cseh S, Hajdú I, et al. Matrix metalloproteinase inhibitors: a critical appraisal of design principles and proposed therapeutic utility. Drugs 2010;70:949-964.

65 Folgueras AR, Pendás AM, Sánchez LM, et al. Matrix metalloproteinases in cancer: from new functions to improved inhibition strategies. Int J Dev Biol 2004;48: 411-424.

66 Freije JM, Balbín M, Pendás AM, et al. Matrix metalloproteinases and tumor progression. Adv Exp Med Biol 2003;532:91-107.

67 Saleh A, Zain RB, Hussaini H, et al. Transcriptional profiling of oral squamous cell carcinoma using formalin-fixed paraffin-embedded samples. Oral Oncol 2010;46:379-386.

68 Stokes A, Joutsa J, Ala-Aho R, et al. Expression profiles and clinical correlations of degradome components in the tumor microenvironment of head and neck squamous cell carcinoma. Clin Cancer Res 2010;16: 2022-2035.

69 Suhr ML, Dysvik B, Bruland O, et al. Gene expression profile of oral squamous cell carcinomas from Sri Lankan betel quid users. Oncol Rep 2007;18: 1061-1075.

70 Toruner GA, Ulger C, Alkan M, et al. Association between gene expression profile and tumor invasion in oral squamous cell carcinoma. Cancer Genet Cytogenet 2004;154:27-35.

71 Zucker S, Cao J, Chen WT. Critical appraisal of the use of matrix metalloproteinase inhibitors in cancer treatment. Oncogene 2004;19:6642-6650.

72 Rehman I, Tactinic keratosisata M, Wu YY, et al. Genetic change in actinic keratoses. Oncogene 1996; 12:2483-2490. 